\title{
GOOD GOVERNANCE IN BANGLADESH: ISSUES AND CHALLENGES
}

\author{
Jannatul Ferdous ${ }^{1 *}$, Saudia Hossain ${ }^{1}$ \\ 1 Department of Public Administration, Comilla University, Cumilla, Bangladesh
}

ABSTRACT - Nowadays governance remains a multi-dimensional concept. It may be termed as a totality of issues reliant on the person concerned about and his/her individual perception of practicality. Good governance cannot be attained, except holding the attention of its vibrant interactions with democratization advantages, the civil rights situation, the state of pro-active improvement and the role of government strategies and programs in a specific nation state. Here, supposed to be a means of consciousness which seems good governance is beneficial due to its various favorable belongings. Good governance simplifies communal and economic progress and concentrates on its surroundings where social privileges are appreciated. Responsibility, competence, effectiveness, and sustainability can affect from people's involvement, which is subsequently vigorous for good governance. On the local area, shared improvement has been associated with good governance. It is correspondingly understood that participatory growth is not thinkable excluding the existence of a vigorous civil society. Democratization in the logic of providing reasonable chances for taking part into political lifespan may closely relate to good governance also. The mode with which good governance has been represented is evidently lacking in Bangladesh. The views that keep an eye on the essence typically consider looking over the prevailing state of concerns vis-a-vis good governance. In observing the current state of affairs, we inquire the question about how much good governance is at all possible. In reply to this question, the importance is engaged in good governance's interconnections with the formation of fresh from of democracy, reinforcement of bureaucracy, combating corruption and rising civil society participation viewpoints.

ARTICLE HISTORY

Received: 29-07-2019

Accepted: 23-11-2019

\section{KEYWORDS}

Governance; governance challenges; Bangladesh

\section{INTRODUCTION}

Bangladesh as an emerging state in south Asia has been beholding various challenges to attaining good governance. Numerous national, as well as international planned elements, have been forcing the country to repair the complications which are extremely upsetting governance in total. Afore talked over the procedures of attaining the aims and purposes of good governance it is essential to examine the main barriers on the way to governance of Bangladesh. Later, after the liberty of Bangladesh in 1971, has witnessed various ascendancy in the governance structure as democracy endured as a democratic scheme was rotated within a one-party megalith; and consecutive military leaders inaugurated a dictatorial structure inside the society. In this prospect, countless efforts have been taken by researchers, consultants, and academia to make a connection between governance and democracy which have exhibited that those two thoughts are mutually to one another and support a state to be a feasible one in obtaining its total progressive objectives (Khan \& Islam, 2015). In the meantime, the word 'good governance' was carried interest as the focus point by international donors and financial organizations. In sounds of good governance in the country has observed a sequence of disappointments which disturbing the entire state machineries which are accountable for underwriting in the direction of a passive and successful community (Khan \& Islam, 2014).

This paper originates with an argument and investigation of the theoretical outline which contains a talk over governance and good governance. The debates that follow focus mostly on appraising the prevailing state of activities vis-a-vis good governance. In observing the present-day state activities, we search the questions about whether good governance is at all possible. In reply to this question, prominence is given to good governance's interconnections of formation of fresh democracy, reinforcement of bureaucracy, combating corruption and rise civil society participation viewpoints.

\section{LITERATURE REVIEW}

The word governance, however, not a new one, but mostly drawn to the concentration of international donors, policy creators, development specialists and academics. Nevertheless, there has not yet been a worldwide settlement of the sense of the term (Khan \& Ahmed, 1997). Governance is seen as the use of political, economic and administrative power to handle a country's activities at all stages. It includes instruments, procedures, and organizations, by which inhabitants and clusters can express their wellbeing's, use their legitimate privileges, obtain their duties, and arbitrate their variances 
(United Nations Development Programme, 1997). The main mechanisms of governance recognized by the OECD are given thus:

a) Validity of government.

b) Responsibility in the means for political and authorized components of government.

c) Capability of governments to create policy and deliver facilities.

d) Admire human freedoms and the rule of law (Vayunandan, 2003).

\section{Good Governance}

The explanations of the upstairs point are as follows: - Firstly, there is recognition of the point that governance contains the practice of power or authority. The second one means, the procedure by which authority or power is applied and through which motive is essential. The Third point indicates that, interconnections and intercommunications in the field of politics, economics, administration, and law in a particular society are of highest significance for the perception related to governance. The Fourth denotes that, such expressions like 'good' and "quality" supposed to be associated with governance (Khan \& Ahmed, 1997). Good governance states the positivity of administration; harmonization and supervision that individuals claim to administer themselves spontaneously (Olson \& Torrance, 1997). ESCAP express that governance can be decent so long as exertions are prepared for diminishing corruption; undertake the opinions of the minorities and the opinions of the utmost helpless segments of community in policy making. Good governance has to be quick to response the existing and upcoming desires of the community. It recognizes eight key features of good governance as:

- Consensual in orientation

- Participating in nature

- Transparent

- Accountable

- Responsive

- Equitable and inclusive

- Effective and efficient

- Rule of law (Islam, 2013).

\section{Poor Governance}

To clear the concept of good governance, its alternative should be identified, viz., the poor governance. Governance contains both progressive and destructive implications, namely, good governance and poor governance. It has been demanded that poor governance is viewed as one of the core reasons for all troubles in the community. A World Bank pamphlet has concise the foremost indicators of poor governance. These are given thus:

\footnotetext{
i. Failure to create a perfect differentiation between what means public and what means private therefore a trend to outright public assets for private advantage;

ii. Failure to form a probable basis of law and government, manners which were favorable to enlargement or arbitrariness in the use of rules and laws;

iii. Executive directions, guidelines, licensing necessities and so on, which hinder, running of markets and inspire rent seeking;

iv. $\quad$ Precedence's, incoherent with growth, bring about in a misdistribution of properties;

v. Extremely hardly grounded or non-transparent judgment constructing Unnecessary costs, low facilities to public and failure to accomplish the goals of the plan and program are other indicators of poor governance (World Bank, 1992).
}

\section{CHALLENGES TO GOVERNANCE OF BANGLADESH}

The country is even now in emerging situations because of its mal organization or mal functionalization of democracy and uncontrolled corruption, it is wounded also by lobbying of public services for low minded individual, group, and political motive. Politicization of public amenities is an ongoing exercise, meanwhile from the beginning of Bangladesh in 1971 as an independent state (Khan \& Islam, 2015). The main features are- lack of democratic exercise, corruption, and politicization of public facilities and the absence of civil society's participation are thoroughly interconnected with the exercise of governance and the attitude of attaining good governance. The state's governance has moved towards numerous challenges since after its freedom. Nevertheless, the key challenges must be instantly traced so as to foster the progress. Bearing in mind about the situation of governance which was built in the three phases this chapter examines three main governance challenges to Bangladesh. 


\section{Formation of Pure form of Democracy}

At present this is predictable that establishment of democratic governance scheme is one of the core challenges and fruitful institutionalization of that kind of scheme could recover the state of governance to look after other challenges efficiently. Therefore, the failure of institutionalization of democratic governance schemes to create the road more unsettled for governance. It is essential to talk over the causes behind why the institutionalization of democratic governance scheme is one of the key trials to the governance issue of Bangladesh (Khan \& Islam, 2015). Later After a long-struggled fight for two spans the people of Bangladesh were capable to overthrow the powers of dictatorship and coming back to a much-desired parliamentary democracy in 1991 (Khan \& Husain, 1996). It invigorated the ambitions and prospects of the individuals for good governance which could carry affluence and progress in their day-to-day survives. The excitement wizened away later, after the successive "democratic" governments were set up which engaged in abuse of public reserves and donate to mal-governance. The Members of Parliament (MPs) and the ministers have been supposed to be corrupt. But maximum time the Parliament has been dysfunctional because of the absence of participation of the main opposition parties and incapable to frequently check and also efficiently supervise the work of the executive. The legislature has been powerless to coordinate the doings of the bureaucracy. Law and order condition declined expressively because of the participation of political parties' leaders in criminal events and terrorism (Khan \& Islam, 2012). Independence of media has been limited typically due to the connection between rich proprietors of print and electronic mass media and dominant and corrupted mechanisms of the society directed towards the murder of honest reporters. A provocative political position of two main political parties has directed towards a condition where every person discovers him/herself in a problematic position. It seems that the institutionalization of parliamentary democracy in the course of earlier two periods goes from a high spirit of tiredness (Khan \& Islam, 2015). Democratic governance has tried to be institutionalized as speedily as probable. Or else, governance may not be in an anticipated state as the existing situation portrays. By reason of under par doings in politics, liable, transparent, participative, effective, efficient, as well as corruption-free administration and government and public facility transfer may not thinkable. This was the actual cause why the institutionalization of democratic governance structure is a foremost governance challenge to Bangladesh.

\section{Strengthening Bureaucracy}

The civil bureaucracy in Bangladesh is apprehended in narrow-minded personal and group-focused politics. Those politics has in cooperation with an inner and an exterior aspect. The inner aspect comprises those dimensions of bureaucratic politics that are followed by bureaucrats at the narrow-level that means, when they communicate with one another either separately or as a group. At this time both the protagonists and antagonists are about the bureaucratic conflict between themselves to continue their authority on the bureaucratic structure. The sectarianism of yester-year, built on the politics of "patriotism," has been exchanged by a much stronger power and also in career-focused intrabureaucracy conflict fueled by extreme ruling-parties intervention (Zafarullah \& Khan, 2001).

From the beginning Generalist civil servants have clashed with specialists/functionalists to continue their governing locus in the public administration of the nation, besides they have been usually prosperous in their initiatives. The external aspect of bureaucratic politics seems civil servants' participation in public politics, which is occasionally seen as straight and noticeable. In the perspective of Bangladesh, this form of participation has been the effect of a mixture of several issues: unfriendliness of clusters either opposite to or unresponsive to ruling party's opinions, politicization of the upper levels of the administration, and substantial bureaucratic contribution in the "civilianization" procedure of military governments. The motives for such participation, nevertheless, have been changed period wise: now and then the guidance derived from the former side, and in others, bureaucrats themselves grabbed with the initiative. However, as a result of such contribution the political character of bureaucrats has outshined their visibly recognized role as impartial, unbiased career civil servants (Zafarullah \& Khan, 2001). Impartiality has misplaced by its applicability in the emerging politicsbureaucracy edges. By the dominance of the bureaucracy in the commercial side of government, particularly in policy making plus execution, it could be simple to undertake its greater tiers, if not the totality of the civil service, to be unconscious to follower fears. It is really a thinkable problem, if the politics of bureaucracy harms society at all.

\section{Combating Corruption}

As far as we know corruption is a universal problem which needs international resolution. It is a worldwide complicated matter. Corruption is a single method or the other one is existent in the meantime of ancient time. Its origins lie profound in bureaucratic and political organizations and its outcome on growth differs with country circumstances. In a country like Bangladesh, corruption and other modes of poor governance is a barrier to the decrease of poverty. Economic development is important to diminish poverty, and corruption brakes growth of economy (Mollah \& Uddin, $\mathrm{n}$. d.). The emerging country Bangladesh offers a distinctive example where corruption has seen as a particularly productive field, notwithstanding the 'existence' of numerous instruments, although unsuccessful, for deal with it. Currently, corruption in Bangladesh is so diffusive that's why it has induced extensive blame from inside the country other than from outside. Superficially, it has even now triggered a national bewilderment as the state has been named as the utmost corrupt nation in the universe (Zafarullah \& Siddiqui, 2001).

The outcome of these three modes of corruption encompasses between one another: greater damages endured by public-sector profits; compelling donor nations and organizations to appoint lobbyists to clear their projects through bribing officials at diverse stages and failure of some projects named Food for Work and aid programs to come at their 
goals owing to enormous robbery and massive ill use of properties. Other destructive results of corruption taking place at the economy contains: siphoning away a huge lump of public properties which could have been effectively employed anywhere in the economy; destabilization of production, efficiency and effectiveness of the government; reduces the wellorganized utilization of capitals and execution of progressive actions; improvements takes place through corruption used either in obvious spending or shifted to foreign bank accounts; produces allocated inadequately by allowing the minimum competent contractor or utmost costly dealer with the uppermost capability to bribe; bribes and grafts in place of accelerating judgments and simplifying movement of records stimulates civil servants to restrain all documents until some payment is prepared for them; money increased from bribes which converts a portion of the predictable earnings; and over-invoicing and under-invoicing of imports and exports and smuggling rises which make possible bias in share choices and to resource flight. Some other similarly negative aspects of corruption remain: weakens public self-confidence over government; stimulates wrong economic selections and obligates government's capability to establish strategies; sorts the poor pay the price; and threatens government's policies of private-segment-focused development (Khan, 2003).

Eradicate corruption is not an easy task as it looks like. Still not a single person rejects the necessity to check corruption successfully. Honestly, it may not be imaginable to eliminate corruption entirely nevertheless strong and discerned activities will go far away to diminish it. The actions which are recommended seem too many and outbrave some easy characterization. To cover and diminish corruption a portion of actions have been suggested. These contains: conduct corruption through generally by unique purges or movements, introduction of anti-corruption boards, commissions and movement for ethical reinforcement or ethical re-armament, consolidation of checks on misuse of authority and the improvement of responsibility of the influential along with public officials, guaranteeing transparency and honesty of governmental doings, grow favorable social outlooks, imposing a code of public moralities, supporting the role of mass media, enlightening educational measures (Theobald, 1990).

\section{Intensification of the Involvement of Civil Society}

Growth related thoughts for Bangladesh frequently emphasis on the economic and social scopes nevertheless is fewer unwilling to discourse the political atmosphere. In the development process the state and market equipment's integrate civil society organizations (CSOs), predominantly non-government organizations (NGOs) (Ahmed, n. d.). NGO-focused civil society could not precede suitable position for political renovation in addition to against the anti-democratic and inhuman initiatives from both the government and political parties. Occasionally they became separated and debated with governmental doings or else the opposition alliance in mediums comprising television talk-shows. Thus, common people professed and caught a message that civil society is situated as the rational groups of political parties, particularly the two chief alliances. Nevertheless, for political renovation, it is essential to make sure a shared outcome of civil society. It desires to generate spaces for debates and negotiations which are important in attaining cooperation and a mutual direction. An independent and modest civil society group can support to bond divides between the groups and work to shape social and political agreement. Civil society must symbolize other devices for the people to attain one voice. Civil society must carry on educating the public about their privileges and accountabilities, their government and its procedure. The civil society is thus far to sit with the leaders of both parties, the prime minister, Sheikh Hasina, and the leader of the BNP-directed alliance, Khaleda Zia, to discover a resolution. Numerous initiatives are taken by civil society alliances but could not prescribe any outcome because they were previously co-opted and dominated by political actors. Thus, they can barely act autonomously and take a position against the extremes of the state. Also, the civil society alliance goes to a particular block and philosophy. They cannot symbolize the entire community that is because of dissimilar views and means of philosophy (Rahaman, 2014).

Civil society groups will be more vigorous towards motivating the political consciousness of the common people and inspiring their political contribution to look after their individual welfares. Through this exertion, governments can become more liable and approachable to the publics' desires; and the elite and the mass people will be more dedicated to democracy. Therefore, a democratic alliance will be attained. In place of using a corporatist method to co-opt civil society and control its sovereignty, states can offer accessible support to civil society institutions to accomplish their purpose more successfully. This support would be in the method of financial support and training for workforces. Furthermore, civil society's sovereignty should not be disrupted. The governments should not need to be scared for an open-minded civil society as it inspires governments to be more truthful, liable, clear and responsive to the public needs, which will gain the support of the individuals and reinforce their legality. A robust civil society institution in a changeover may deliver profitable networks for democratic contribution. They can support to reconstruct citizens' faith in the government, stimulate their privileges and self-interests, and inspire the presence of minorities and disenfranchised clusters. However, the possibility or capability of civil society in Bangladesh in the direction of democracy cannot make us positive if they convert themselves free from the enchantment of political groups and parties along with individual benefits.

\section{CONCLUSION AND IMPLICATIONS}

Now-a-days good governance has arisen entirely to conquer the focusing point of the world. Yet, there are numerous conversations and argument relating to its significance and within which conditions precede good governance can turn into an actuality. Investigation into good governance has stretched a definite phase of matureness when it can be viewed as a form of all-inclusive standpoints. This mode of observing thought has improved the probability of its broader use of different philosophies and realms. The scenario of Bangladesh and good governance is still lasting far away from each other. By the means of those four measures which talk over earlier, Bangladesh's score is miserably decreasing. In 
Bangladesh the outlook of good governance is pale. Nevertheless, the extension of the self-governing government, election type republic, and exercise of parliamentary government may eventually recover the state of affairs. The political beliefs will progressively develop more adaptive for the growth of good governance of the country if democracy grows an open-minded sample in the country (Khan, 2002). The main duty, lays both the political leaders and the political parties who need to work together information about this procedure. The progress of a civil society needs robust enough to monitor and force the community to be more answerable and clearer which will be the decisive need for good governance.

\section{REFERENCES}

Caccese, J. B., Buckley, T. A., Tierney, R. T., Arbogast, K. B., Rose, W. C., Glutting, J. J., \& Kaminski, T. W. (2018). Head and neck size and neck strength predict linear and rotational acceleration during purposeful soccer heading. Sports Biomechanics, 17(4), 462-476. https://doi.org/10.1080/14763141.2017.1360385

Huang, X., Sun, J., \& Sun, J. (2018). A car-following model considering asymmetric driving behavior based on long short-term memory neural networks. Transportation Research Part C: Emerging Technologies, 95(February), 346-362. https://doi.org/10. Ahmed, S. (n. d.). The Civil Society of Bangladesh: Depoliticized in Working Agenda but Politicized in Power Relation. Retrieved from: https://journal.hass.tsukuba.ac.jp/interfaculty/article/viewFile/16/64

Islam, M. J. (2013). Law on Good Governance: Bangladesh Perspective. Dhaka: New Warsi Book Corporation.

Khan, M. M. \& Ahmed, A. K. M. (1997). Dimensions of Governance. In M. G. Qibria (ed.) The Bangladesh Economy in Transition (pp.302-326). Delhi: Oxford University Press.

Khan, M. M. \& Islam, M. S. (2015). Governance Challenges in Bangladesh. In A. Dawoody, (ed.) Public Administration and policy in the Middle East, (pp. 281-295). New York: Springer.

Khan, M. M., \& Islam, M. S. (2014). Democracy and Good Governance in Bangladesh: Are They Compatible? Millennial Asia, 5(1), 23-40.

Khan, M. M. \& Islam, M. S. (2012). Democracy and good governance in Bangladesh: Are they compatible? Paper presented at NAPSIPAG 9th International Conference, 12-14 December, Sri- Lanka.

Khan, M. M. (2003). Political and Administrative Corruption: Concepts, Comparative Experiences and Bangladesh Case. Asian Affairs, 25(1): 55-83.

Khan, M. M. (2002). Good Governance: Concept and the Case of Bangladesh. In Thirty Years of Bangladesh Politics: Essays in Memory of Dr. Mahfuzul Huq (pp. 63-76). Dhaka: The University Press Limited.

Khan, M. M. \& Husain, S. A. (1996). Process of democratization in Bangladesh. Contemporary South Asia, 5(3), pp. 319-334.

Mollah, M. A. H. \& Uddin, M. N. (n. d.). Combating Corruption in Bangladesh: Some Strategies. Retrieved from: http://unpan1.un.org/intradoc/groups/public/documents/unpan/unpan009521.pdf

Olson, D. R. \& Torrance, N. (1997). The Hand Book of Education and Human Development. Massachusetts, USA: Black Well Publishers Ltd.

Rahaman, M. M. (September 14, 2014). Towards democracy: role of civil society. New Age, Retrieved from: http://archive.newagebd.net/49176/towards-democracy-role-of-civil-society/

Theobald, R. (1990). Corruption Development and Underdevelopment. London: Macmillan.

United Nations Development Programme, (1997). A UNDP Policy Paper: Strategy on Governance. New York.

Vayunandan, E. (2003). Development and Reforms in Good Governance with Special Reference to India. In E. Vayunandan \& D. Mathew (eds.). Good Governance Initiatives in India. New Delhi: Prentice-Hall of India Private Limited.

World Bank, (1992). Governance and Development. Washington D. C.: World Bank Publications.

Zafarullah, H. \& Khan, M. M. (2001). Bureaucracy in Bangladesh: Politics within and the Influence of Partisan Politics. In A. Farazmand (ed.) Handbook of Comparative and Development Administration (pp. 989-1005). New York: Marcel Dekkaer Inc.

Zafarullah, H. \& Siddiqui, N. A. (2001). Dissecting Public Sector Corruption in Bangladesh: Issues and Problems of Control. Public Organization Review: A Global Journal, 1: 465-486.1016/j.trc.2018.07.022

James, S. L., Abate, D., Abate, K. H., Abay, S. M., Abbafati, C., Abbasi, N., Abbastabar, H., Abd-Allah, F., Abdela, J., Abdelalim, A., Abdollahpour, I., Abdulkader, R. S., Abebe, Z., Abera, S. F., Abil, O. Z., Abraha, H. N., Abu-Raddad, L. J., Abu-Rmeileh, N. M. E., Accrombessi, M. M. K., ... Murray, C. J. L. (2018). Global, regional, and national incidence, prevalence, and years lived with disability for 354 diseases and injuries for 195 countries and territories, 1990-2017: a systematic analysis for the Global Burden of Disease Study 2017. The Lancet, 392(10159), 1789-1858. https://doi.org/10.1016/S0140-6736(18)32279-7

Tan, H., Qin, L., Jiang, Z., Wu, Y., \& Ran, B. (2018). A hybrid deep learning based traffic flow prediction method and its understanding. Transportation Research Part C: Emerging Technologies, 90(January), 166-180. https://doi.org/10.1016/j.trc.2018.03.001

Taylor, K., Post, A., Hoshizaki, T. B., \& Gilchrist, M. D. (2019). The effect of a novel impact management strategy on maximum principal strain for reconstructions of American football concussive events. Proceedings of the Institution of Mechanical Engineers, Part P: Journal of Sports Engineering and Technology, 233(4), 503-513. https://doi.org/10.1177/1754337119857434 